\title{
PERAN PEMBIMBING PENYULUHAN ISLAM DALAM REHABILITASI SOSIAL KEAGAMAAN PADA DEWASA TERLANTAR
}

\author{
Farah Nadiyah Hilmy \\ Fakultas Ushuludin Adab dan Dakwah IAIN Ponorogo \\ farahnadiyah@gmail.com
}

\begin{abstract}
This study aims to find the efforts of Islamic counseling supervisors in solving the problems of neglected adults at the Social Rehabilitation Unit of Bina Karya Madiun in Ponorogo, methods of Islamic counseling guidance in meeting the needs of neglected adults at the Social Rehabilitation Unit of Bina Karya Madiun in Ponorogo. To answer the questions above, this research is a case study research type, the researcher uses a qualitative descriptive approach. Data collection techniques used are through observation, interviews, and documentation. For technical data analysis using data reduction, data presentation, and drawing conclusions. The results of the study briefly show that the efforts made by Islamic counseling supervisors in solving neglected adult problems according to the field are planning, implementation and evaluation. Islamic counseling guidance methods in meeting the needs of neglected adults according to the field are lectures, dialogues and questions and answers, consultations, talaqqi.
\end{abstract}

Keywords: Islamic Counseling Guidance, social rehabilitation, adults

\begin{abstract}
Abstrak
Penelitian ini bertujuan untuk menemukan upaya pembimbing penyuluhan Islam dalam penyelesaian masalah dewasa terlantar di Unit Rehabilitasi Sosial Bina Karya Madiun di Ponorogo metode bimbingan penyuluhan Islam dalam memenuhi kebutuhan dewasa terlantar di Unit Rehabilitasi Sosial Bina Karya Madiun di Ponorogo. Untuk menjawab pertanyaan diatas, penelitian ini merupakan jenis penelitian studi kasus, peneliti menggunakan pendekatan deskriptif kualitatif. Teknik pengumpulan data yang digunakan yaitu melalui observasi, wawancara, dan dokumentasi. Untuk teknis analisis data dengan menggunakan reduksi data, penyajian data, dan penarikan kesimpulan. Hasil penelitian secara ringkas menunjukkan bahwa upaya yang dilakukan pembimbing
\end{abstract}


penyuluhan islam dalam penyelesaian masalah dewasa terlantar menurut dilapangan yaitu perencanaan, pelaksanaan dan evaluasi. metode bimbingan penyuluhan Islam dalam memenuhi kebutuhan dewasa terlantar menurut dilapangan yaitu ceramah, dialog dan tanya jawab, konsultasi, talaqqi.

\section{Kata Kunci: Bimbingan Penyuluhan Islam, rehabilitasi sosial, dewasa}

\section{PENDAHULUAN}

Pada masa dewasa ini banyak sekali harapan yang ditujukan pada mereka yang memang berada pada masa ini. Banyak sekali tugas-tugas yang harus dikembangkan dan tingkat penguasaan ini akan sangat memengaruhi tingkat keberhasilan mereka ketika sudah berusia beranjak tua. Maka tidak jarang ditemukannya beberapa permasalahan yang dihadapi oleh orang-orang dewasa. Seseorang yang sudah dewasa apabila tidak dapat berhasil dalam tugas-tugas perkembangannya akan mengalami kendala dalam menjalai kehidupanya. Berbagai peran baru tersebut merupakan masalah berat yang harus dihadapi oleh usia dewasa pada umumnya. Akibatnya ketika orang dewasa tidak mampu menjalankan peran ataupun tugas dalam memenuhi kebutuhannya mereka tidak sedikit memilih hidup menelantar ataupun menggelandang. Pengertian orang terlantar adalah seseorang yang karena tertentu, miskin atau tidak mampu, yang tidak dapat terpenuhi kebutuhan dasarnya dengan wajar baik secara jasmani, rohani, maupun sosialnya. Jadi dengan demikian orang terlantar juga termasuk pengemis dan gelandangan. Mereka tidak bisa memenuhi kebutuhan hidupnya sendiri. ${ }^{1}$ Untuk itu perlu adanya upaya yang strategis dalam manangani permasalahan tersebut, baik dari pihak masyarakat atau sosialnya, keluarga, pemerintah maupun lembaga-lembaga non pemerintah yang bergerak di bidang penanganan masalah sosial. Maka dari itu peran pembimbing penyuluhan islam sangat dibutuhkan disini, mengingat tugas penyuluh adalah sebagai agen perubahan masyarakat yang mampu mengarahkan, mengembangkan kegiatan bimbingan melalui bahasa agama. ${ }^{2}$ Bentuk bimbingan sosial ini diantaranya

${ }^{1}$ Joko Arif, Peran Pekerja Sosial dalam Merehabilitasi Masalah Pengemis, Gelandangan, dan Orang Terlantar (Pgot) di Panti Pelayanan Sosial Pgot Mardi Utomo Semarang. (Surakarta: IAIN Surakarta, 2017), 18.

${ }^{2}$ Ramlah, Meretas Dakwah di Kota Palopo, (Yogyakarta: CV Budi Utama, 2019), 190. 
mencakup bimbingan fisik dan kesehatan, bimbingan mental dan spiritual hidup bermasyarakat yang termasuk bagian peran penting di balai rehabilitasi sosial dengan tujuan membantu individu menjadi insan yang berakhlakul kharimah. ${ }^{3}$ Disisi lain balai rehabilitasi sosial juga bekerja sama dengan penyuluh dalam rehabilitasi sosial keagamaan.

Peran (role) termasuk aspek dinamis dari kedudukan (status) artinya, seseorang telah melaksanakan hak-hak dan kewajibannya sesuai dengan kedudukannya, maka orang itu telah melaksanakan suatu peran. Peran dapat diartikan sebagai perilaku individu yang penting bagi struktur sosial masyarakat. ${ }^{4}$ Jadi kata peran yang dimaksud dalam penelitian ini yaitu perilaku seseorang dalam status kedudukannya di masyarakat. Sehingga dapat disimpulkan bahwa peran adalah aspek dinamis berupa perilaku atau tindakan yang dilakukan oleh orang atau badan lembaga yang menduduki suatu posisi dalam situasi sosial.

Dalam KBBI pengertian penyuluh menurut bahasa berasal dari kata "suluh" yang berarti benda yang dipakai untuk menerangi. Dalam bahasa sehari hari istilah penyuluh sering digunakan sebagai pemberian penerangan, yang diambil dari kata suluh yang sama artinya dengan "obor". 5 Jadi kata peran yang dimaksud dalam penelitian ini yaitu perilaku seseorang dalam status kedudukannya di masyarakat. Sehingga dapat disimpulkan bahwa peran adalah aspek dinamis berupa perilaku atau tindakan yang dilakukan oleh orang atau badan lembaga yang menduduki suatu posisi dalam situasi sosial.

Peran penyuluh bukan hanya melakukan penyuluhan agama dalam artian berupa pengajian saja, akan tetapi seluruh kegiatan pemahaman baik berupa bimbingan ataupun penerangan di berbagai progam pembangunan. Dilihat dari posisi penyuluh saat ini bahwasannya sangat strategis bagi penyuluh dalam melakukan tugas atau misi

${ }^{3}$ Zahro Aminatuz, Peran Bimbingan dan Penyuluhan Islam dalam Rehabilitasi Sosial Keagamaan Pada Lanjut Usia Terlantar di Unit Rehabilitasi Sosial "Mandiri" Semarang II, (Semarang: UIN Walisongo, 2014), 4-5.

${ }^{4}$ J. Dwi Narwoko, Dan Bagong Suyanto, Sosiologi Tes Pengantar dan Terapan, (Jakarta:Kencana, 2007), Cet Ke-3, 158-159

${ }^{5}$ Kamus Besar Bahasa Indonesia, Pusat Bahasa Departemen Pendidikan Nasional Edisi Ketiga, (Jakarta: Balai Pustaka, 2005), 1101. 
keagamaan maupun pembangunan dengan rasa tanggung jawab yang dapat membawa masyarakat kepada kehidupan yang aman dan sejahtera.

Fungsi informatif dan edukatif yaitu sebagai penyuluh agama islam selain dirinya juga sebagai dai yang berkewajiban mendakwahkan Islam, penyuluh juga menyampaikan pemahaman atau penerangan agama serta mendidik masyarakat sebaik-baiknya sesuai dengan tuntutan Al-qur'an dan Sunnah Nabi. Fungsi konsultatif yaitu penyuluh agama Islam juga berfungsi menjadikan dirinya untuk turut memikirkan dan memecahkan persoalan-persoalan yang dihadapi masyrakat, baik persoalan-persoalan pribadi, keluarga atau persoalan masyarakat secra umum. Fungsi advokatif yaitu pembelaan ataupun dukungan positif yang bertujuan mengupayakan solusi bagi suatu masalah melalui kebijaan publik. Sedangkan selain beberapa fungsi tersebut tugas pokok penyuluh agama yaitu melakukan dan mengembangkan kegiatan bimbingan atau penyuluhan serta pembangunan melalui bahasa agama lalu juga memberikan konsultasi arahan dalam meningkatkan ketaqwaan dan kerukunan umat beragama. ${ }^{6}$

Dalam penyuluhan maka diperlukan beberapa teknik penyuluhan diantaraya perencanaan, pelaksanaan, evaluasi maka perlu adanya penggunaan metode di dalamnya. Metode sendiri mempunyai makna cara teratur atau bersistem yang digunakan untuk melaksanakan suatu pekerjaan guna mencapai tujuan yang ditentukan. ${ }^{7}$ Ceramah dari aspek segi bahasa dapat diartikan sebagai penuturan atau penerangan secara lisan oleh guru pendidikan agama islam terhadap peserta didiknya di dalam kelas. Alat yang digunakan yaitu "berbicara". Sementara pengisi ceramah menyampaikan materinya kepada para peserta atau audien mendengarkan dengan teliti mencatat pokok pokok penting yang telah dikemukakan. ${ }^{8}$ Metode dialog yaitu percakapan atau silih berganti anatara dua orang atau lebih yang didalamnya terdapat tujuan dan topik tertentu serta mempunyai manfaat bagi pelaku dan pendengarnya. Dialog juga merupakan cara yang efektif dan menyenangkan dalam menyampaikan suatu pesan sebagaimana yang telah

\footnotetext{
${ }^{6}$ Ramlah, Meretas Dakwah di Kota Palopo, (Yogyakarta: cv budi utama, 2019), 190.

${ }^{7} \mathrm{Https}: / / \mathrm{www}$.google.com/amp/s/kbbi.web.id/metode.htnl

8 Syahraini Tambak, Metode Ceramah: Konsep Dan Aplikasi Dalam Pembelajaran Pendidikan Agama Islam, Jurnal Tarbiyah, Vol. 21, No.2, Juli-Desember 2014
} 
dicontohkan oleh Allah SWT dan Rasulullah SAW. ${ }^{9}$ Metode tanya jawab adalah cara penyajian pelajaran dalam bentuk pertanyaan, yang dikemukakan oleh guru yang harus dijawab oleh siswa. Konsultasi adalah pertukaran untuk mendapatkan kesimpulan nasihat, saran, dan sebagainya yang sebaik baiknya. ${ }^{10}$ Metode Talaqqi dari segi bahasa diambil dari pada perkataan yaitu belajar secara berhadapan dengan guru. Sering pula disebut musyafahah, yang bermakna dari mulut ke mulut (pelajar belajar Al-Qur'an dengan memperhatikan gerak bibir guru untuk mendapatkan pengucapan makhraj yang benar). ${ }^{11}$

Rehabilitasi merupakan gabungan antara kata " $r$ " yang berarti kembali dan "habilitasi" adalah kemampuan. Sehingga rehabilitasi sendiri dapat diartikan secara umum sebuah proses untuk membantu sesuatu agar dapat kembali seperti sedia kala, atau paling tidak terdapat pengganti yang sama seperti sebelumnya. ${ }^{12}$

Keagamaan berasal dari kata agama yang kemudian mendapat awalan "ke" dan akhiran "a" sehingga membentuk kata baru yaitu "keagamaan". Sehingga keagamaan di sini mempunyai arti segenap kepercayaan kepada Tuhan serta dengan ajaran kebaikan dan kewajiban yang berkaitan dengan kepercayaan itu. ${ }^{13}$

Pengertian orang terlantar adalah seseorang yang karena tertentu miskin/tidak mampu, yang tidak dapat terpenuhi kebutuhan dasarnya dengan wajar baik secara jasmani, rohani, maupun sosialnya. Sehingga dengan demikian orang terlantar juga termasuk pengemis dan gelandangan. Mereka tidak bisa memenuhi kebutuhan hidupnya sendiri. $^{14}$

${ }^{9}$ Djamarah Syaiful Bahri, Pola Asuh Orang Tua Dan Komunikasi Dalam Keluarga, (Jakarta: Rineka Cipta, 2014), hal. 198-199.

${ }^{10}$ https://www.google.com/amp/s/kbbi.web.id/konsultasi.html

${ }^{11}$ Abdul Qawi, Peningkatan Prestasi Belajar Hafalan Al-Qur'an Melalui Metode Talaqqi Di Mtsn Gampong Teungoh Aceh Utara, Jurnal Ilmiah Islam Futura Vol. 16. No. 2, Februari 2017

${ }_{12}$ Sri Astutik, Rehabilitsi Sosial, http://digilib.uinsby.ac.id/id/eprint/20029, terakhir diakses 14 agustus 2020

${ }^{13}$ Departemen Pendidikan dan Kebudayaan, Kamus Besar Bahasa Indonesia, edisi II (Jakarta: Balai Pustaka, 1986), 10

${ }^{14}$ Joko Arif, Peran Pekerja Sosial dalam Merehabilitasi Masalah Pengemis, Gelandangan, dan Orang Terlantar (Pgot) di Panti Pelayanan Sosial Pgot Mardi Utomo Semarang.( Surakarta: IAIN Surakarta, 2017), 4. 


\section{METODE PENELITIAN}

Jenis penelitian ini adalah penelitian kualitatif. Penelitian kualitatif adalah suatu penelitian ilmiah yang bertujuan untuk memahami suatu fenomena dalam konteks sosial secara alamiah dengan mengedepankan proses interaksi komunikasi yang mendalam antara peneliti dengan fenomena yang diteliti. Penelitian ini adalah penelitian kualitatif yaitu penelitian yang menghasilkan penelitian yang valid dan sesuai realita yang ada. ${ }^{15}$ Penelitian ini menggunakan metode penelitian studi kasus (case study). Pendekatan penelitian yang digunakan dalam penelitian ini adalah pendekatan deskriptif kualitatif, karena peneliti menganalisis dan menggambarkan peneliti secara objektif dan mendetail untuk mendapatkan hasil yang akurat terkait pada penelitian ini, yang berfokus untuk mengetahui peran pembimbing penyuluhan Islam dalam rehabilitasi sosial keagamaan pada dewasa terlantar yang berada di unit rehabilitasi sosia bina karya Madiun di Ponorogo.

\section{HASIL PENELITIAN DAN PEMBAHASAN}

Upaya pembimbing penyuluhan Islam dalam penyelesaian masalah dewasa terlantar di unit rehabilitasi sosial bina karya madiun di ponorogo adalah perencanaan dalam mempersiapkan pelaksanaan penyuluhan diantaranya kerjasama dengan dinas sosial provinsi Jawa Timur yang menaungi unit rehabilitasi sosial bina karya Madiun di Ponorogo, menerima SK dari povinsi Jawa Timur, menerima jadwal kegiatan penyuluhan, koordinasi rutin dengan pengurus setiap 1 bulan sekali (teknis, jadwal, materi dan evaluasi). Untuk pelaksanaan penyuluhan diakukan secara terjadwal dan berkesinambungan yaitu pelaksanaan bimbingan penyuluhan Islam dengan tema mental agama dan bimbingan penyuluhan Islam dengan tema baca tulis al-qur'an. Kemudian evaluasi berupa penilaian mengenai hal yang sudah tercapai dalam penyuluhan dan kekurangan yang menjadi hambatan penyuluhan. untuk metode bimbingan penyuluhan Islam dalam memenuhi kebutuhan dewasa terlantar di Unit Rehabilitasi Sosial Bina

\footnotetext{
${ }^{15}$ Lexy J. Moleong, Metodologi Peneltian Kualitatif, (Bandung: PT. Rosdakarya)1994., 3
} 
Karya Madiun di Ponorogo diantaranya ceramah, dialog dan tanya jawab, konsultasi dan talaqqi.

\section{PENUTUP}

Bimbingan Penyuluhan Islam mampu membantu upaya penyelesaian masalah yang dialami individu dengan rentang usia dewasa sehingga membantu upaya pemulihan secara psikis individu yang berada di unit rehabilitasi sosial bina karya madiun di Kabupaten Ponorogo. Saran untuk peneliti selanjutnya adalah menggunakan teknik lain yang diduga mampu mengatasi pengentasan masalah individu di unit rehabilitasi sosial madiun di Kabupaten Ponorogo.

\section{DAFTAR RUJUKAN}

Abdul Qawi. Peningkatan Prestasi Belajar Hafalan Al-Qur'an Melalui Metode Talaqqi Di Mtsn Gampong Teungoh Aceh Utara, Jurnal Ilmiah Islam Futura Vol. 16. No. 2, Februari, 2017.

Amirah diniaty. Evaluasi Bimbingan Konseling. Riau: Zanafa Publishing, 2012.

Aminatuz Zahro. Peran Bimbingan dan Penyuluhan Islam dalam Rehabilitasi Sosial Keagamaan Pada Lanjut Usia Terlantar di Unit Rehabilitasi Sosial "Mandiri" Semarang II. Semarang: UIN Walisongo, 2014.

Arif Joko. Peran Pekerja Sosial dalam Merehabilitasi Masalah Pengemis, Gelandangan, dan Orang Terlantar (Pgot) di Panti Pelayanan Sosial Pgot Mardi Utomo Semarang. Surakarta: IAIN Surakarta, 2017.

Departemen Pendidikan dan Kebudayaan. Kamus Besar Bahasa Indonesia, edisi II. Jakarta: Balai Pustaka, 1986.

Djamarah Syaiful Bahri, Pola Asuh Orang Tua Dan Komunikasi Dalam Keluarga, (Jakarta: Rineka Cipta, 2014), hal. 198-199

J. Dwi Narwoko, Dan Bagong Suyanto, Sosiologi Tes Pengantar dan Terapan, (Jakarta:Kencana, 2007), Cet Ke-3, 158-159

Lexy J. Moleong. Metodologi Penelitian Kualitatif. Bandung: PT. Rosdakarya, 1994. 
Rosyada: Islamic Guidance and Counseling

Vol 2. No. 22021

Puput Syaiful Rohman. Penelitian Kualitatif, 2009.

Ramlah. Meretas Dakwah di Kota Palopo. Yogyakarta: Cv Budi Utama, 2019.

Sri Astutik, Rehabilitsi Sosial, http://digilib.uinsby.ac.id/id/eprint/20029, terakhir diakses 14 Agustus 2020

Syahraini Tambak, Metode Ceramah: Konsep Dan Aplikasi Dalam Pembelajaran Pendidikan Agama Islam, Jurnal Tarbiyah, Vol. 21, No.2, Juli-Desember 2014 